\title{
Exploiting B Cell Receptor Analyses to Inform on HIV-1 Vaccination Strategies
}

\author{
Christoph Kreer ${ }^{1} \mathbb{D}^{(}$, Henning Gruell ${ }^{1,2}$, Thierry Mora ${ }^{3}{ }^{\complement}$, Aleksandra M. Walczak ${ }^{3}$ and \\ Florian Klein $1,2,4, *$ \\ 1 Laboratory of Experimental Immunology, Institute of Virology, Faculty of Medicine and University Hospital \\ Cologne, University of Cologne, 50931 Cologne, Germany; christoph.kreer@uk-koeln.de (C.K.); \\ henning.gruell@uk-koeln.de (H.G.) \\ 2 German Center for Infection Research, Partner Site Bonn-Cologne, 50931 Cologne, Germany \\ 3 Laboratoire de Physique de l'École Normale Supérieure (PSL University), CNRS, Sorbonne Université, \\ Université de Paris, 75005 Paris, France; tmora@phys.ens.fr (T.M.); awalczak@lpt.ens.fr (A.M.W.) \\ 4 Center for Molecular Medicine Cologne (CMMC), University of Cologne, 50931 Cologne, Germany \\ * Correspondence: florian.klein@uk-koeln.de
}

Received: 25 November 2019; Accepted: 24 December 2019; Published: 1 January 2020

\begin{abstract}
The human antibody repertoire is generated by the recombination of different gene segments as well as by processes of somatic mutation. Together these mechanisms result in a tremendous diversity of antibodies that are able to combat various pathogens including viruses and bacteria, or malignant cells. In this review, we summarize the opportunities and challenges that are associated with the analyses of the B cell receptor repertoire and the antigen-specific B cell response. We will discuss how recent advances have increased our understanding of the antibody response and how repertoire analyses can be exploited to inform on vaccine strategies, particularly against HIV-1.
\end{abstract}

Keywords: B lymphocytes; B cell receptors; antibodies; antibody repertoire; immunoglobulin; Rep-seq; Ig-seq; vaccination strategy; HIV-1; broadly neutralizing antibodies

\section{Introduction}

In order to protect from a vast number of different pathogens, human $B$ cells are able to generate a remarkable diversity of different $B$ cell receptors (BCRs). During B cell development and maturation, these receptors are built by recombination and mutation processes resulting in a virtually unlimited number of different antibodies (i.e., soluble BCRs). However, certain pathogens, such as HIV-1, challenge the immune system by the ability to rapidly escape from immune pressure [1,2], resulting in an ongoing adaptation of the immune response against these pathogens. This evolutionary arms race between pathogens and the immune system leaves footprints in our immunological memory that can describe developmental pathways towards an adapted immune response. Deciphering these pathways holds the potential to greatly improve our understanding of critical steps in lymphocyte receptor development and may inform on novel vaccination strategies. For a long time, experimental setups and bioinformatics pipelines were limited in assessing the diversity of lymphocyte receptor repertoires or in identifying subtle immunological imprints after infections or vaccinations. The advent of advanced single cell cloning and next generation sequencing (NGS) methods has revolutionized the field and opened the door to investigate adaptive immune receptor repertoires (AIRR) at an unprecedented depth. In this review, we summarize recent developments that have fostered our understanding of B cell biology and antibody responses. Focusing on the development of highly potent broadly neutralizing antibodies against HIV-1, we discuss how a detailed knowledge of the human B cell repertoire may support the development of novel vaccination strategies. 


\section{B Cell Receptor Diversity}

Antibodies are composed of heavy and light chains, both of which are divided into a constant and a variable region (Figure 1a). The different isotypes for the heavy chain constant regions mediate different effector functions and are grouped into the classes $\operatorname{IgM}$, IgD, IgG1-4, IgA1-2, and IgE [3]. The variable regions of heavy and light chains form the paratope that contacts the epitope on a particular antigen (e.g., on a bacterial or viral surface protein). Two essential steps act during the lifespan of a B cell to generate B cell receptor diversity: (i) the V(D)J recombination process that builds the naïve (i.e., antigen-inexperienced) B cell repertoire, and (ii) somatic hypermutation (SHM) during the process of affinity maturation that generates high affinity $B$ cell receptors and antibodies (i.e., the antigen-experienced repertoire).

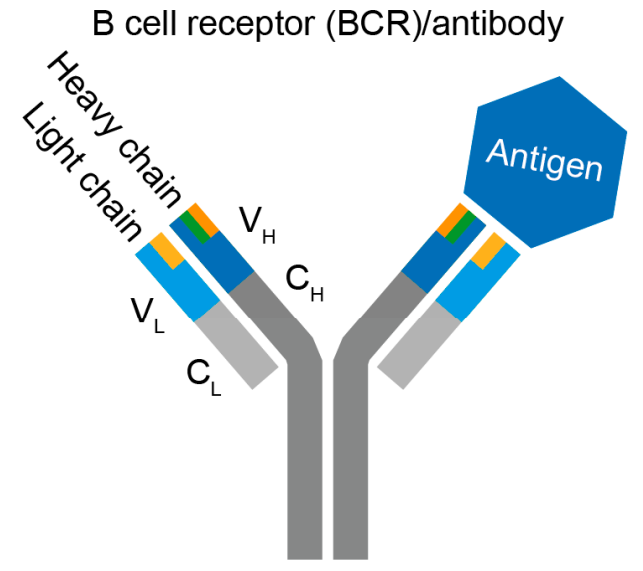

(a)

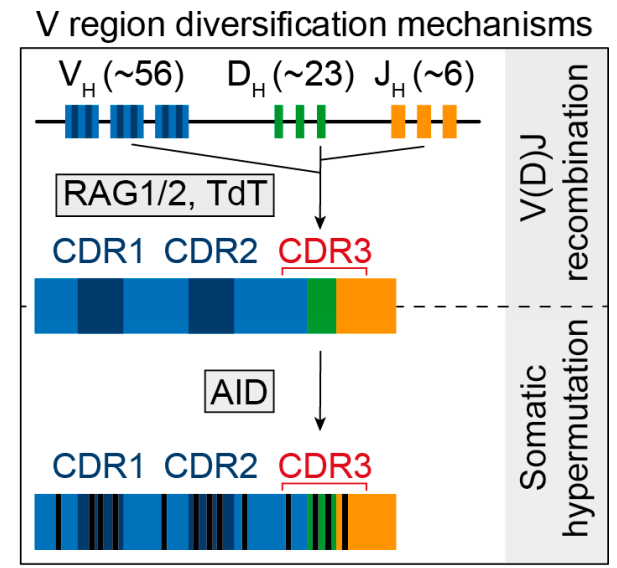

(b)

Figure 1. Structure and generation of B cell receptors (BCRs)/antibodies. (a) Schematic representation of an antibody. BCRs are composed of heavy $(\mathrm{H})$ and light $(\mathrm{L})$ chains, which can be separated into variable (V) and constant (C) regions. Heavy and light chain variable regions make contact with the antigen. Light chain constant regions come in two different isotypes (kappa and lambda) and heavy chain constant regions in five (IgM, IgD, IgG1-4, IgA1-2, and IgE; not depicted). (b) V region diversification mechanisms. $\mathrm{V}(\mathrm{D}) \mathrm{J}$ recombination forms the CDR3s of the naïve B cell receptors. During the process of affinity maturation, somatic hypermutation mediated by activation-induced deaminase (AID) results in the development of mutations within B cell receptors/antibodies. RAG1/2: Recombination-activating gene $1 / 2$, TdT: terminal deoxynucleotidyl transferase, CDR1/2/3: complementarity determining region 1/2/3.

The initial diversity of the B cell repertoire results from the assembly of the B cell receptor during early $B$ cell development in the bone marrow. The recombination-activating gene (RAG) $1 / 2$ enzymes recombine variable $(\mathrm{V})$, diversity $(\mathrm{D})$, and joining $(\mathrm{J})$ gene segments of the immunoglobulin heavy $(\mathrm{IgH})$ chain locus to first assemble the heavy chain variable region, followed by $\mathrm{V}$ and $\mathrm{J}$ gene segment recombination within the Ig kappa (IgK) and Ig lambda (IgL) loci [4]. Junctional diversity is further increased by RAG1/2 and other enzymes through the generation of palindromic (P) nucleotides, as well as by the terminal deoxynuclotidyl transferase (TdT) through the addition of non-template (N) nucleotides [5] (Figure 1b). Heavy and light chain V genes exclusively encode for two complementarity determining regions (CDR1 and CDR2) that are usually structurally exposed at the tip of the antibody and contribute to antigen recognition. A third CDR (CDR3) is generated by the $\mathrm{V}(\mathrm{D}) \mathrm{J}$ recombination process and is the most variable part within $\mathrm{B}$ cell receptors and antibodies. The CDRs are interspersed and flanked with framework regions (FWR) that mainly function as a scaffold for the overall immunoglobulin (Ig) fold. However, mutations in FWRs have been shown to also influence binding affinity as well as neutralizing activity [6,7].

There are currently at least 56 functional V, 23 D, and $6 \mathrm{~J}$ genes described for the IgH locus [8], which results in a theoretical combinatorial number of 7728 different heavy chain variable regions. 
The IgK locus can recombine to 205 different kappa light chain variable regions from $41 \mathrm{~V}$ and $5 \mathrm{~J}$ genes, whereas the IgL locus might recombine up to 165 different lambda light chains from $33 \mathrm{~V}$ and $5 \mathrm{~J}$ genes [8]. Combinatorial pairing of heavy and light chains yields a theoretical diversity of about $2.9 \times 10^{6}$ different antibodies. Including the $\mathrm{P} / \mathrm{N}$ nucleotides, the theoretical number of different antibody sequences is vastly higher than the total number of estimated $B$ cells in the human body $\left(10^{12}\right)$ [9]. However, all those antibody sequences are not equally likely to be generated. Their generation probability spans 30 orders of magnitude for $\operatorname{IgH}$ alone $[9,10]$, with additional diversity being generated by insertions and deletions [11]. Of note, due to sampling issues, the number of $B$ cell clones whose size falls below the detection threshold is unknown, rendering estimates of total B cell counts unreliable $[12,13]$.

Naïve B cells circulate between secondary lymphoid tissues (e.g., lymph nodes and spleen) until they recognize their cognate antigen [14]. Upon antigen contact, B cells can be recruited to lymphatic structures called germinal centers present in secondary lymphoid tissues. There, the recognition event is able to trigger a second step of diversification called affinity maturation. Affinity maturation is mediated by the enzyme activation-induced deaminase (AID) as well as B cell expansion and selection [15]. AID introduces SHM including substitutions, insertions, and deletions into the variable regions, generating possible progenies that express $\mathrm{B}$ cell receptors that get selected for higher antigen affinity (Figure 1b) $[15,16]$. SHM is favored but not limited to hot spot motifs and multiple SHM hotspots have been identified $[17,18]$. In addition to their context preference, SHMs tend to occur close to each other along the sequence [10]. They are typically more pronounced in the CDRs than in the framework regions due to positive selection as well as higher frequency of AID motifs [18]. Including SHM into the calculation of potential BCRs results in an almost infinite number of different receptors. Finally, AID activity is able to mediate heavy chain class switch from $\operatorname{IgM} / \operatorname{IgD}$ to $\operatorname{IgG}$, $\operatorname{IgA}$, or $\operatorname{IgE}$. Different $B$ cell subtypes and antibody classes are of critical importance and their functions have been reviewed elsewhere $[3,14,19]$.

\section{Challenges and Advances in B Cell Receptor Analyses}

Dissecting the humoral immune response is a challenging task. Analyses of antibodies on the serum level, for example by ELISA, affinity chromatography, or mass spectrometry [20], are usually limited to characterizing the polyclonal antibody response. Genetic B cell analyses, on the other side, facilitate single cell (i.e., single antibody) resolution. To this end, antibody-coding nucleic acids (DNA or RNA) are extracted from B cells, amplified, and sequenced (Figure 2). Importantly, complete sequences of matched heavy and light chains allow for recombinant production of antibodies and thus allow studying antibody functions on a monoclonal level (Figure 2). In this section, we describe the challenges arising at the different steps of genetic BCR analyses and discuss advantages and disadvantages of individual strategies.

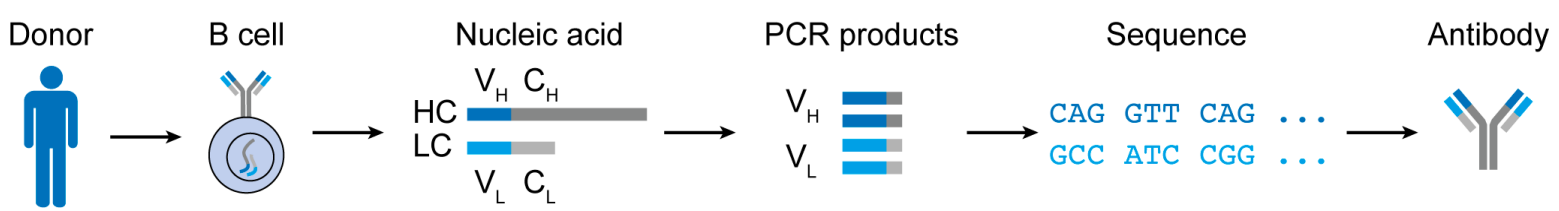

Figure 2. Analyzing B cell receptors from human donors. B cells are isolated, and DNA or RNA is extracted and subjected to B cell receptor sequence amplification. Amplicons are sequenced and can be used for recombinant antibody production. HC: heavy chain, LC: light chain, V: variable region, C: constant region, $\mathrm{V}_{\mathrm{H}}$ : heavy chain variable region, $\mathrm{V}_{\mathrm{L}}$ : light chain variable region.

\subsection{Subset Identification}

B cells can be subdivided into different subsets. These comprise (i) B cells at different developmental stages (e.g., pro-B cells, immature B cells, mature B cells), (ii) antigen-naive and antigen-experienced B cells, (iii) functional subsets, such as regulatory, effector, or memory B cells, or iv.) B cells with defined 
specificity (e.g., HIV-1 $1_{\text {Env }}$-reactive). Depending on the scientific question, it is often required to analyze an individual B cell subset and identification of such subsets can take place at distinct steps of an experimental pipeline (Figure 3, first row).

Different $B$ cell subsets can be enriched or isolated by sorting techniques such as magnetic-activated cell sorting (MACS) or fluorescence-activated cell sorting (FACS) [21,22]. Importantly, FACS allows collecting and further processing target cells either in bulk approaches or as single cells in multi-well plates. Recently, novel microencapsulation systems have been used to encapsulate single B cells into picoliter droplets $[23,24]$. The combination of single cell encapsulation with fluorescence-activated sorting (fluorescence-activated droplet sorting (FADS), reviewed in [25]) allows processing of single antigen-specific B cells in compartments that are a million times smaller than the wells of multi-well plates, which significantly increases the throughput capacity.

In order to isolate antigen-specific B cells, one of the following approaches (reviewed in [26,27]) can be applied (Figure 3, first row): (i) Antigen-derived baits that are fluorescently labeled can be used to identify and sort antigen-reactive B cells. This can be achieved by fluorescently-labeled proteins [28-34], antigens presented on virus-like particles [35,36] or cells [37], or by pathogens themselves [38]. (ii) Antibody libraries that are expressed on phages or yeast cells can be selected for binding to antigen-derived proteins or whole pathogens $[39,40]$. Of note, however, the random pairing of heavy and light chains in combinatorial libraries does not allow to infer a representative picture of the underlying antibody response. (iii) Single B or plasma cells or immortalized B cells can be expanded and stimulated to secrete antibodies that can be tested for antigen-binding or neutralizing activity [41-44]. Importantly, recombinant proteins and other baits that are used for selecting antigen-specific antibodies can critically differ in their structure and glycosylation pattern from their native counterpart. Indeed, the generation of optimized bait proteins [30] or native-like envelope trimers [45] were critical steps to improve the isolation of potent HIV-1 broadly neutralizing antibodies (bNAbs) by antigen-specific sorting strategies [31,46-48]. Very recently, a combination of single cell co-encapsulation and DNA-tagged recombinant proteins has even been used to directly map antibody sequences to their antigen specificity [49].

\subsection{Pairing of Heavy and Light Chains}

Direct heavy or light chain RT-PCR and sequence analyses from bulk-sorted B cells allow to infer B cell repertoire characteristics such as clonal distributions, V(D)J recombination, and somatic hypermutation [50-55]. However, the native pairing information of heavy and light chains is essential to fully describe an individual antibody, e.g., for recombinant expression. Although pairing information can be restored to some extent from bulk analyses (i.e., by bioinformatic approaches) [56], the most robust way to achieve these information is either by single cell sorting into multi-well plates [57-60] or by co-encapsulation of single cells and RNA-capture or barcode beads (e.g., with the $10 \times$ Genomics chromium system) in picoliter droplets [23,24,61-65] (Figure 3, second row). Single cell sorting into multiwell plates is typically limited in throughput to tens of thousands of cells, whereas encapsulation systems allow throughputs of hundreds of thousands of cells. However, droplet occupancy follows a Poisson distribution and requires limiting dilutions of the sample and beads [61]. As a consequence, the majority of all droplets remains empty or contains only unpaired cells or beads, which can lead to a high loss of input material. Alternatives for heavy and light chain paring comprise combinatorial yeast or phage display libraries that can be screened for reactivity (reviewed in [66]). However, due to their stochastic nature, such display approaches also contain artificial heavy and light chain pairs.

\subsection{PCR Coverage}

All current approaches require an initial PCR-based amplification of the BCR-encoding DNA or mRNA/cDNA. The diversity of the B cell repertoire poses distinct challenges to this amplification step: (i) All possible V gene segments need to be covered by the PCR and (ii) priming sites may have been somatically hypermutated and are therefore prone to decreased amplification efficiencies (Figure 3 , 
third row). PCR amplification of antibody heavy and light chains has thus been performed with $\mathrm{V}$ gene-specific multiplex primer mixes $[57,58,67-71]$. The majority of these primers were designed against the $5^{\prime}$ end of the coding region of the $\mathrm{V}$ gene, which is sufficient for amplifying most antibody sequences. However, HIV-1 bNAbs, for instance, have been shown to accumulate high levels of SHM as well as insertions and deletions $[7,30,72,73]$. In order to increase priming efficiency, primer mixes have been designed against the $5^{\prime}$ end of the less-mutated leader region that encodes the antibody secretion peptide. These mixes have been demonstrated to be superior for the isolation of highly mutated HIV-1-reactive antibodies [72,74].

Whereas primer sets perform well in single cell cloning approaches, they may introduce primer biases in bulk PCR amplification approaches [75]. This can pose a critical disadvantage. A method that is able to overcome this limitation is the rapid amplification of $5^{\prime}$ cDNA ends (5'RACE) [76], which has been adapted to bulk [77] and single cell approaches [60,78]. Commonly applied protocols include template-switching (TS) reverse transcription, which introduces a TS-oligo during cDNA synthesis. The TS-oligo bears a universal priming site that can be used together with a constant region reverse primer to amplify any antibody variable region independent of the incorporated $\mathrm{V}$ gene segment.

\subsection{Sequencing and Bioinformatics}

Sequence analysis of amplified heavy and light chains can be demanding in several aspects (Figure 3, fourth row). First, depending on the B cell subset of interest, the required throughput can vary from a few hundred to millions of antibody sequences. Second, the sequencing method needs to reliably cover the whole region of interest (variable region $\sim 500-600 \mathrm{bp}$ ). Third, SHM needs to be distinguishable from sequencing errors, thus requiring low sequencing error rates or error-correction techniques.

Classical Sanger sequencing is frequently employed in the analyses of B cell receptor subsets such as antigen-specific memory B cells in the blood $[34,79,80]$. Due to the inability to sequence bulk-amplified heavy and light chains, next generation sequencing (NGS) techniques such as pyro-, ion-semiconductor-, or illumina dye sequencing are typically preferred over sanger sequencing for high-throughput analyses [50-55]. However, they often suffer from shorter read lengths and higher error rates. Molecular barcoding techniques and bioinformatics pipelines have been developed to account for both PCR- and sequencing-induced errors [81]. To this end, unique molecular identifiers (UMI) are introduced during cDNA generation by template-switching reverse transcription. Moreover, protocols for long read parallel sequencing (e.g., SMRT and Nanopore sequencing) have been recently applied to analyze BCR sequences [63,82].

Finally, high-throughput analyses of millions of different antibody sequences require advanced bioinformatics pipelines. Several bioinformatics tools have been reported [83] and standardized protocols on reporting antibody sequences have been developed by the Adaptive Immune Receptor Repertoire (AIRR) Community $[84,85]$. A detailed description of the methods applied is beyond the scope of this review and they are covered in previous reviews $[83,86]$. 
Challenges
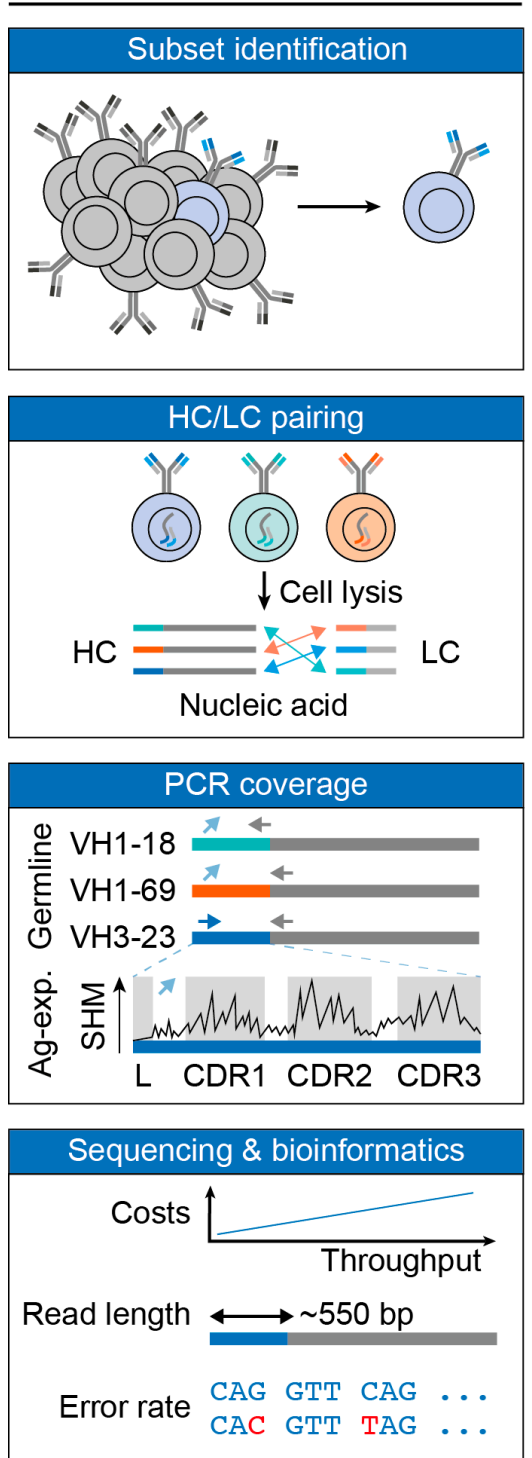

Technical solutions

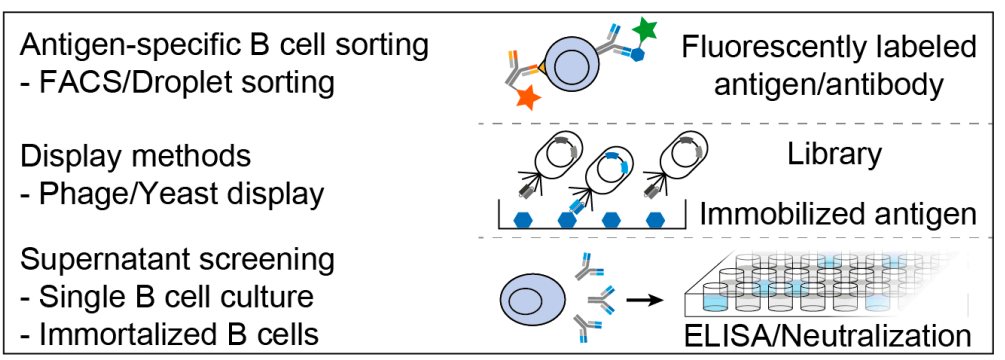

Single cell compartmentalization

- Multiwell plate/chip

- Emulsion/Picodroplets

Combinatorial approaches

- Display methods

- Bioinformatically

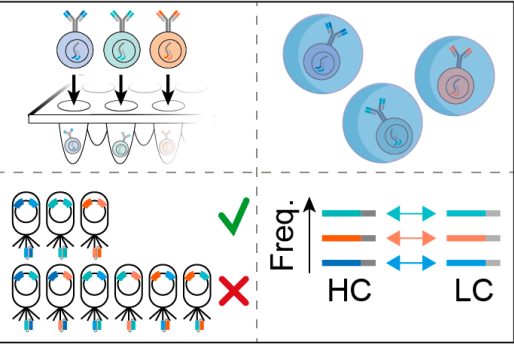

Primer set optimization

- $V$ gene primer mixes

- Leader binding

Universal binding site

- Template switch RT

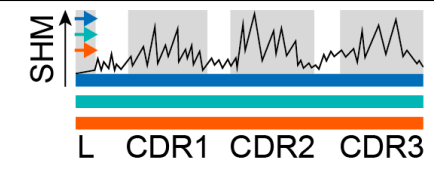

mRNA

+Adapter $-\downarrow$
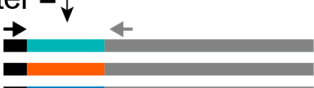

Next generation sequencing

- Parallel sequencing of millions of molecules

Bioinformatic error correction

- Unique molecular identifier

(UMI)

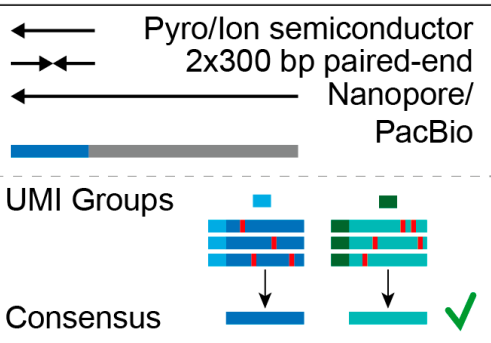

Figure 3. Technical solutions to challenges for B cell receptor analyses. HC: heavy chain, LC: light chain, Freq: frequency, Ag-exp: antigen-experienced, SHM: somatic hypermutation, VH: V gene segment of the heavy chain, $\mathrm{L}$ : leader region, CDR1/2/3: complementarity determining region 1/2/3, mRNA: messenger RNA.

\section{Informing about Vaccination Strategies (I): Molecular Characterization of Broadly HIV-1 Neutralizing Antibodies}

Only a small fraction of HIV-1-infected individuals develop highly potent bNAbs and detailed analyses of $B$ cell receptors and antibodies at a single cell level have been limited to a few dozen subjects. Nevertheless, these critical investigations have revealed sequence and structural characteristics of potent HIV-1 neutralizing antibodies that were repeatedly observed across different individuals. These features can include high levels of somatic hypermutation, the presence of unusual insertions or deletions, and/or long heavy chain CDR3 (CDRH3) regions. Thus, vaccine-mediated HIV-1 bNAb induction may require specifically tailored strategies for $\mathrm{B}$ cell activation and maturation.

Isolated highly potent bNAbs can serve as templates for the development of such strategies. Over the last decade, numerous bNAbs have been identified by bait-specific single cell sorts or B cell microcultures. Most of these antibodies were obtained from the memory B cell pool as well as, occasionally, from plasma cells $[72,87,88]$. This suggests that both, memory and antigen-secreting 
B cells, can in principle serve as a valuable source for bNAb isolation and characterization. All HIV-1 bNAbs target epitopes on the HIV-1 envelope protein (Env) that include the CD4 binding site (CD4bs), glycan-dependent targets on the variable Env loops (V1/V2, V3), the fusion peptide and the membrane-proximal external region (MPER) of gp41, and sites spanning the gp120 and gp41 subunits $[27,89]$.

In clinical trials, bNAbs have been shown to suppress viremia and delay the time to viral rebound after interruption of antiretroviral therapy (ART) [90-96]. Of most relevance for HIV-1 vaccine efforts, however, bNAbs are highly effective in preventing infection in animal models [97-100]. As proof-of-concept trials for passive immunization using the CD4bs bNAb VRC01 in humans are ongoing (ClinicalTrials.gov: NCT02716675, NCT02568215), it is widely believed that induction of potent bNAbs by vaccination will confer protection from HIV-1.

Among the highly potent HIV-1 bNAbs, antibodies of the VRC01- and 8ANC131-classes target the CD4 binding site (CD4bs) on the HIV-1 Env. They are particularly noteworthy for their restricted $\mathrm{V}$ gene usage $[30,72,101]$ facilitating the VH1-2 or VH1-46 gene segments. Importantly, members of the potent VRC01-class of bNAbs have now been identified in at least 12 individuals, demonstrating their capacity to be reproducibly induced $[30,72,88,101-106]$. Such a reproducible development of very similar antibodies in different individuals is often referred to as convergent or stereotypical antibody responses or described as "public antibodies". Identifying convergent immune responses is informative for vaccine design because strategies that induce such a repeatedly observed type of immune reaction may be broadly applicable on a population-level. Indeed, B cell analyses have revealed convergent $\mathrm{V}$ gene responses not only against HIV-1 but several pathogens after infection and/or vaccination (Table 1).

Table 1. Convergent antibody $\mathrm{V}$ gene usage in natural infection and in vaccine trials.

\begin{tabular}{|c|c|c|c|c|}
\hline VH & VL & Pathogen & Donor & Reference \\
\hline \multirow[t]{2}{*}{ IGHV1-2 } & - & DENV $^{1}$ & Acute Dengue Infection & {$[107]$} \\
\hline & - & HIV-1 & HIV-1-Infected & {$[30,72,101,102,104]$} \\
\hline IGHV1-3 & - & $\mathrm{HBV}^{2}$ & $\begin{array}{l}\text { HBV-Associated Acute Liver } \\
\text { Failure Patients }\end{array}$ & [108] \\
\hline \multirow[t]{2}{*}{ IGHV1-18 } & - & Influenza A & $\begin{array}{c}\text { Participants of Influenza Vaccine } \\
\text { Trial }\end{array}$ & {$[32]$} \\
\hline & - & DENV & Acute Dengue Infection & [107] \\
\hline \multirow[t]{2}{*}{ IGHV1-46 } & - & $\mathrm{RV}^{3}$ & RV-Infected Adults/Infants & [109-111] \\
\hline & - & HIV-1 & HIV-1-Infected & {$[72,112]$} \\
\hline \multirow[t]{4}{*}{ IGHV1-69 } & - & Influenza A & $\begin{array}{l}\text { Hu. Non-Immune Antibody } \\
\text { Phage-Display Library }\end{array}$ & [113] \\
\hline & & & Seasonal Influenza Vaccinees & [114] \\
\hline & & & Human Donor with Influenza A & [115] \\
\hline & & HIV-1 & Broadly Neutralizing Serum & [72 101.116] \\
\hline \multirow{2}{*}{ IGHV3-7 } & - & HBV & HBV Vaccinees & [117] \\
\hline & - & Influenza A & Vaccinated Healthy Individuals & {$[118]$} \\
\hline \multirow[t]{3}{*}{ IGHV3-15 } & IGLV1-40 & $\mathrm{EBOV}^{4}$ & rVSV-ZEBOV ${ }^{5}$ Vaccinees & [34] \\
\hline & & & ChAD3 EBOV 6 Vaccinees & [119] \\
\hline & & & $\begin{array}{c}\text { Survivor of } 2014 \text { EBOV Outbreak } \\
\text { in Zaire }\end{array}$ & {$[120]$} \\
\hline
\end{tabular}


Table 1. Cont.

\begin{tabular}{|c|c|c|c|c|}
\hline VH & VL & Pathogen & Donor & Reference \\
\hline \multirow[t]{2}{*}{ IGHV3-23 } & IGKV2D-29 & $\mathrm{Hib}^{7}$ & $\begin{array}{l}\text { Hib-PS }{ }^{8} \text { Conjugate-Vaccinated } \\
\text { Infants }\end{array}$ & [121] \\
\hline & IGKV1-5 & $\mathrm{ZIKV}^{9}$ & $\begin{array}{l}\text { Brazilian/Mexican DENV- and } \\
\text { ZIKV-Infected Individuals }\end{array}$ & [33] \\
\hline \multirow[t]{4}{*}{ IGHV3-30 } & IGKV3-11 & $\mathrm{HCMV}^{10}$ & HCMV-Infected Individuals & [122] \\
\hline & & $\begin{array}{l}\text { Streptococcus } \\
\text { pneumonieae }\end{array}$ & N/A & [123] \\
\hline & - & ZIKV & ZIKV-Infected Donors & {$[124,125]$} \\
\hline & & & $\begin{array}{l}\text { Phage-Display Naive Antibody } \\
\text { Library }\end{array}$ & [126] \\
\hline IGHV4-30-4 & & RV & RV-Infected Adults/Infants & [109] \\
\hline IGHV4-1 & & RV & RV-Infected Adults/Infants & [109] \\
\hline IGHV4-39 & & $\mathrm{RV}$ & RV-Infected Adults/Infants & [109] \\
\hline IGHV4-61 & & RV & RV-Infected Adults/Infants & [109] \\
\hline IGHV5-51 & - & HIV-1 & HIV-1-Infected & [127] \\
\hline
\end{tabular}

VRC01-class CD4bs bNAbs demonstrate the same mode of CD4bs recognition that is dominated by the CDR2 of the heavy chain (CDRH2) [101]. To avoid steric clashes, they share an additional restriction for use of an unusually short (five amino acids) light chain CDR3 (CDRL3), which is found in only $\sim 1 \%$ of antibodies $[102,128]$. Finally, they show extensive levels of somatic hypermutation of up to $>30 \%$ on the nucleotide level (i.e., $>100$ mutations) from their inferred antibody germline sequences $[30,72,102,104]$.

Members of HIV-1 bNAb classes targeting other epitopes are generally less restricted in terms of their $\mathrm{V}$ gene usage but often share other sequence and structural characteristics. For example, bNAbs binding to the V1/V2 apex region typically carry CDRH3s of extraordinary length that are required to penetrate the extensive Env glycan shield $[129,130]$. Compared to the average CDRH3 lengths of approximately 15 amino acids in the naïve and memory B cell receptor repertoires [131], V1/V2-targeting bNAbs have been identified that have $>2$-fold longer CDRH3s (e.g., VRC26.25 and PGDM1400 with CDRH3 lengths of $\geq 34$ aa [31,48]). Similarly, relatively long CDRH3s are also found in HIV-1 bNAbs targeting other glycan-related epitopes (e.g., V3 loop, gp120/gp41 interface) or the gp41 MPER [89]. In addition, some bNAbs display poly- and/or autoreactivity [132,133], features that are often associated with long CDRH3s and are generally counterselected during B cell maturation [57]. Overall, the consistent observation of one or multiple rare features in potent HIV-1 bNAbs highlights some of the difficulties for their induction through vaccination. However, several antibodies with considerable breadth and potency but lower levels of somatic hypermutation and more regular CDRH3 lengths have now been identified $[36,105,134,135]$. These antibodies may be more readily inducible and serve as blueprints for facilitating vaccine strategies.

\section{Informing about Vaccination Strategies (II): B Cell Receptor Repertoire Analyses}

Due to the unusual sequence and structural characteristics of most highly potent HIV-1 bNAbs, unconventional approaches to vaccination are likely to be required. Strategies that have been proposed include epitope-based and antibody lineage-based vaccine designs [136]. Epitope-based vaccination strategies use immunogens that mimic the general structure of vulnerable Env sites, in principle allowing for the development of multiple bNAb classes against the same target region. However, when reverted to their inferred germline sequence, many HIV-1 bNAbs show considerably reduced or fully 
abrogated binding to HIV-1 Env [72,137-139]. To this end, antibody-lineage based vaccination strategies employ designed immunogens that interact with inferred unmutated bNAb precursors to initiate the development of a particular bNAb lineage [140]. Although bNAb precursor cell frequency in the repertoire is only one of a number of factors that will determine the potential success of lineage-based vaccine design, a comprehensive understanding of the composition of the $\mathrm{B}$ cell receptor repertoire in healthy individuals can provide critical information to guide the development of vaccination pathways [141].

As seen for the majority of antibodies, most potent HIV-1 bNAbs are strongly dependent on interactions mediated by the CDR3 of the heavy chain. Compared to the distribution in the overall memory B cell repertoire, many HIV-1 bNAbs have relatively long CDRH3s which have been suggested to be largely generated during VDJ recombination [142]. Particularly long CDRH3s are required for many bNAbs targeting the V1/V2 apex region of Env. Notably, among näive B cell repertoires of healthy individuals, CDRH3 lengths of 28 amino acids and more have been identified in less than $0.5 \%$ of sequences [142], and a CDRH3 length of 30 amino acids as seen for bNAb PG9 was found to be exceedingly rare $(0.01 \%)$ [143]. Although this suggests difficulties for CDRH3-based HIV-1 vaccination, the potential contribution of BCR repertoire analyses to vaccine design was recently demonstrated when precursor frequencies of the CDRH3-dominated bNAb BG18 [144,145] were determined to inform on the selection of an immunogen targeting BG18-like precursors [146]. Among $1 \times 10^{9} \mathrm{CDRH} 3$ sequences from a total of 14 healthy donors, BG18-like sequences were identified in all individuals $[55,146]$. Importantly, rare immunogen-reactive B cells could subsequently be isolated from additional healthy donors [146]. Moreover, antibody lineage-based vaccination strategies that aim to engage precursors of the VRC01-class of CD4bs bNAbs have entered the clinical stage with the germline-targeting immunogen eOD-GT8 (ClinicalTrials.gov: NCT03547245) [147]. As mentioned before, antibodies of this class are particularly restricted for usage of the VH1-2*02 allele and a 5 amino acid CDRL3 [101]. BCR repertoire analyses revealed that potential VRC01-class precursor B cells are exceptionally rare [147-149]. In addition, allelic variation can result in the lack of naïve B cells derived from the key VH1-2*02 allele [149]. Nevertheless, eOD-GT8-reactive naïve B cells could be identified in a majority of HIV-1-negative donors $(14 / 18)$ [147,148], providing repertoire analysis-based support for advancing the eOD-GT8 immunogen to be evaluated in a clinical setting.

While germline-targeting immunogens are designed to initiate a particular B cell lineage, subsequent immunizations with additional antigens will likely be required to induce the development of broad and potent mature antibodies through additional rounds of affinity maturation [140]. To this end, interrogations of the natural development of bNAbs in HIV-1 elite neutralizers may be highly informative for immunogen design. High-throughput parallel sequencing methods of the $B$ cell receptor repertoire combined with bioinformatical processing and phylogenetic analyses have facilitated to reconstruct the inferred development of antibody lineages [56,102-105,135,139,150-158]. Of note, when informed by template sequences of bNAbs obtained through single cell approaches, high-throughput BCR sequencing methods can identify antibodies with higher breadth and potency [159]. Of particular relevance for vaccine design, longitudinal studies that investigate the co-evolution of HIV-1 and the neutralizing antibody response in single individuals may provide guidance for the design of antigens driving bNAb potency and breadth. For example, several studies revealed that development of broad neutralization was preceded by viral diversification and/or supported by antibody helper lineages that selected for viral variants that drove bNAb development [135,152,154,156-158,160,161]. While these observations support a stepwise immunization approach, "dead-end" limbs of antibody lineages appear during the affinity maturation process. Therefore, sequential immunogens will need to be carefully selected $[48,135,156,157]$.

Besides the lineage specific analyses, high-throughput NGS approaches have also been used to investigate the whole B cell receptor repertoire of HIV-1-infected individuals either from combinatorial libraries [162-164] or from PBMCs or purified B cells [75,154,165-168]. A recent study by Waltari et al. detected slight shifts in $\mathrm{V}$ gene family usage, higher degrees of somatic hypermutation, and 
longer CDRH3s for HIV-1-infected individuals [167]. However, other studies could not find any differences but report variation within healthy or HIV-1-infected individuals to be as large as between the different cohorts $[75,166]$. The current sampling and sequencing depths might therefore still hamper the identification of HIV-1 infection-induced changes on the B cell receptor repertoire.

\section{Conclusions}

Only a small fraction of HIV-1-infected individuals is able to mount a broadly neutralizing serum activity against HIV-1. Over the last decade, advances in screening methods and single cell cloning techniques enabled the isolation of numerous broadly neutralizing antibodies. These antibodies have been shown to be promising candidates for HIV-1 treatment and prevention. However, molecular analyses also revealed special characteristics such as $\mathrm{V}$ gene restriction, long CDRH3s, and/or high loads of SHM, which may restrict the development of highly potent bNAbs in natural infection and hamper their induction by current vaccination strategies.

To overcome potential roadblocks for the induction of bNAbs through vaccination, a number of strategies have been proposed. All of these, however, will require the interaction of one or multiple immunogens with $B$ cell receptors to effectively drive bNAb development. Thus, a detailed understanding of the naïve $B$ cell receptor repertoire and the constantly adapting antibody response in the context of HIV-1 infection can be highly informative for vaccine design. Novel experimental and bioinformatics pipelines have the capacity to integrate neutralization, antibody sequence, and structural data. These methods hold great promise to identify common pathways of potent immune responses that will be critical for developing effective vaccination strategies.

Author Contributions: Conceptualization, C.K. and F.K.; literature review, C.K., H.G., T.M., A.M.W., and F.K.; writing-original draft preparation, C.K., H.G., and F.K.; writing-review and editing, C.K., H.G., T.M., A.M.W., and F.K.; visualization, C.K.; funding acquisition, T.M., A.M.W., and F.K. All authors have read and agreed to the published version of the manuscript.

Funding: This work was supported by the German Center for Infection Research (DZIF), the German Research Foundation (CRC 1279, CRC 1310), and the European Research Council (ERC-StG639961 and ERC-COG724208).

Acknowledgments: We thank all members of the Klein Lab for helpful discussions.

Conflicts of Interest: The authors declare no conflict of interest.

\section{References}

1. Parvin, J.D.; Moscona, A.; Pan, W.T.; Leider, J.M.; Palese, P. Measurement of the mutation rates of animal viruses: Influenza A virus and poliovirus type 1. J. Virol. 1986, 59, 377-383. [CrossRef]

2. Starcich, B.R.; Hahn, B.H.; Shaw, G.M.; McNeely, P.D.; Modrow, S.; Wolf, H.; Parks, E.S.; Parks, W.P.; Josephs, S.F.; Gallo, R.C.; et al. Identification and characterization of conserved and variable regions in the envelope gene of HTLV-III/LAV, the retrovirus of AIDS. Cell 1986, 45, 637-648. [CrossRef]

3. Vidarsson, G.; Dekkers, G.; Rispens, T. IgG subclasses and allotypes: From structure to effector functions. Front. Immunol. 2014, 5, 520. [CrossRef]

4. Alt, F.W.; Zhang, Y.; Meng, F.L.; Guo, C.; Schwer, B. Mechanisms of programmed DNA lesions and genomic instability in the immune system. Cell 2013, 152, 417-429. [CrossRef] [PubMed]

5. Komori, T.; Okada, A.; Stewart, V.; Alt, F.W. Lack of N regions in antigen receptor variable region genes of TdT-deficient lymphocytes. Science 1993, 261, 1171-1175. [CrossRef] [PubMed]

6. Boyer, S.; Biswas, D.; Kumar Soshee, A.; Scaramozzino, N.; Nizak, C.; Rivoire, O. Hierarchy and extremes in selections from pools of randomized proteins. Proc. Natl. Acad. Sci. USA 2016, 113, 3482-3487. [CrossRef] [PubMed]

7. Klein, F.; Diskin, R.; Scheid, J.F.; Gaebler, C.; Mouquet, H.; Georgiev, I.S.; Pancera, M.; Zhou, T.; Incesu, R.B.; $\mathrm{Fu}$, B.Z.; et al. Somatic mutations of the immunoglobulin framework are generally required for broad and potent HIV-1 neutralization. Cell 2013, 153, 126-138. [CrossRef] 
8. Lefranc, M.P.; Giudicelli, V.; Ginestoux, C.; Bodmer, J.; Muller, W.; Bontrop, R.; Lemaitre, M.; Malik, A.; Barbie, V.; Chaume, D. IMGT, the international ImMunoGeneTics database. Nucleic Acids Res. 1999, 27, 209-212. [CrossRef]

9. Sethna, Z.; Elhanati, Y.; Callan, C.G.; Walczak, A.M.; Mora, T. OLGA: Fast computation of generation probabilities of B- and T-cell receptor amino acid sequences and motifs. Bioinformatics 2019, 35, 2974-2981. [CrossRef]

10. Marcou, Q.; Mora, T.; Walczak, A.M. High-throughput immune repertoire analysis with IGoR. Nat. Commun. 2018, 9, 561. [CrossRef]

11. Elhanati, Y.; Sethna, Z.; Marcou, Q.; Callan, C.G., Jr.; Mora, T.; Walczak, A.M. Inferring processes underlying B-cell repertoire diversity. Philos. Trans. R. Soc. B Biol. Sci. 2015, 370, 20140243. [CrossRef] [PubMed]

12. Vollmers, C.; Sit, R.V.; Weinstein, J.A.; Dekker, C.L.; Quake, S.R. Genetic measurement of memory B-cell recall using antibody repertoire sequencing. Proc. Natl. Acad. Sci. USA 2013, 110, 13463-13468. [CrossRef] [PubMed]

13. Mora, T.; Walczak, A.M. How many different clonotypes do immune repertoires contain? Curr. Opin. Syst. Biol. 2019, 18, 104-110. [CrossRef]

14. Schroeder, H.W.; Cavacini, L., Jr. Structure and function of immunoglobulins. J. Allergy Clin. Immunol. 2010, 125, S41-S52. [CrossRef] [PubMed]

15. Victora, G.D.; Nussenzweig, M.C. Germinal centers. Annu. Rev. Immunol. 2012, 30, 429-457. [CrossRef]

16. Teng, G.; Papavasiliou, F.N. Immunoglobulin somatic hypermutation. Annu. Rev. Genet. 2007, 41, 107-120. [CrossRef]

17. Yaari, G.; Vander Heiden, J.A.; Uduman, M.; Gadala-Maria, D.; Gupta, N.; Stern, J.N.; O'Connor, K.C.; Hafler, D.A.; Laserson, U.; Vigneault, F.; et al. Models of somatic hypermutation targeting and substitution based on synonymous mutations from high-throughput immunoglobulin sequencing data. Front. Immunol. 2013, 4, 358. [CrossRef]

18. Schramm, C.A.; Douek, D.C. Beyond Hot Spots: Biases in Antibody Somatic Hypermutation and Implications for Vaccine Design. Front. Immunol. 2018, 9, 1876. [CrossRef]

19. LeBien, T.W.; Tedder, T.F. B lymphocytes: How they develop and function. Blood 2008, 112, 1570-1580. [CrossRef]

20. De Costa, D.; Broodman, I.; Vanduijn, M.M.; Stingl, C.; Dekker, L.J.; Burgers, P.C.; Hoogsteden, H.C.; Sillevis Smitt, P.A.; van Klaveren, R.J.; Luider, T.M. Sequencing and quantifying IgG fragments and antigen-binding regions by mass spectrometry. J. Proteome Res. 2010, 9, 2937-2945. [CrossRef]

21. Plouffe, B.D.; Murthy, S.K.; Lewis, L.H. Fundamentals and application of magnetic particles in cell isolation and enrichment: A review. Rep. Prog. Phys. 2015, 78, 016601. [CrossRef] [PubMed]

22. Ibrahim, S.F.; van den Engh, G. Flow cytometry and cell sorting. Adv. Biochem. Eng. Biotechnol. 2007, 106, 19-39. [PubMed]

23. Eyer, K.; Doineau, R.C.L.; Castrillon, C.E.; Briseno-Roa, L.; Menrath, V.; Mottet, G.; England, P.; Godina, A.; Brient-Litzler, E.; Nizak, C.; et al. Single-cell deep phenotyping of IgG-secreting cells for high-resolution immune monitoring. Nat. Biotechnol. 2017, 35, 977-982. [CrossRef] [PubMed]

24. Shembekar, N.; Hu, H.; Eustace, D.; Merten, C.A. Single-Cell Droplet Microfluidic Screening for Antibodies Specifically Binding to Target Cells. Cell Rep. 2018, 22, 2206-2215. [CrossRef] [PubMed]

25. Xi, H.D.; Zheng, H.; Guo, W.; Ganan-Calvo, A.M.; Ai, Y.; Tsao, C.W.; Zhou, J.; Li, W.; Huang, Y.; Nguyen, N.T.; et al. Active droplet sorting in microfluidics: A review. Lab Chip 2017, 17, 751-771. [CrossRef] [PubMed]

26. Wilson, P.C.; Andrews, S.F. Tools to therapeutically harness the human antibody response. Nat. Rev. Immunol. 2012, 12, 709-719. [CrossRef]

27. Walker, L.M.; Burton, D.R. Passive immunotherapy of viral infections: 'Super-antibodies' enter the fray. Nat. Rev. Immunol. 2018, 18, 297-308. [CrossRef]

28. Scheid, J.F.; Mouquet, H.; Feldhahn, N.; Walker, B.D.; Pereyra, F.; Cutrell, E.; Seaman, M.S.; Mascola, J.R.; Wyatt, R.T.; Wardemann, H.; et al. A method for identification of HIV gp140 binding memory B cells in human blood. J. Immunol. Methods 2009, 343, 65-67. [CrossRef]

29. Scheid, J.F.; Mouquet, H.; Feldhahn, N.; Seaman, M.S.; Velinzon, K.; Pietzsch, J.; Ott, R.G.; Anthony, R.M.; Zebroski, H.; Hurley, A.; et al. Broad diversity of neutralizing antibodies isolated from memory B cells in HIV-infected individuals. Nature 2009, 458, 636-640. [CrossRef] 
30. Wu, X.; Yang, Z.Y.; Li, Y.; Hogerkorp, C.M.; Schief, W.R.; Seaman, M.S.; Zhou, T.; Schmidt, S.D.; Wu, L.; $\mathrm{Xu}, \mathrm{L} . ;$ et al. Rational design of envelope identifies broadly neutralizing human monoclonal antibodies to HIV-1. Science 2010, 329, 856-861. [CrossRef]

31. Sok, D.; van Gils, M.J.; Pauthner, M.; Julien, J.P.; Saye-Francisco, K.L.; Hsueh, J.; Briney, B.; Lee, J.H.; Le, K.M.; Lee, P.S.; et al. Recombinant HIV envelope trimer selects for quaternary-dependent antibodies targeting the trimer apex. Proc. Natl. Acad. Sci. USA 2014, 111, 17624-17629. [CrossRef] [PubMed]

32. Joyce, M.G.; Wheatley, A.K.; Thomas, P.V.; Chuang, G.Y.; Soto, C.; Bailer, R.T.; Druz, A.; Georgiev, I.S.; Gillespie, R.A.; Kanekiyo, M.; et al. Vaccine-Induced Antibodies that Neutralize Group 1 and Group 2 Influenza A Viruses. Cell 2016, 166, 609-623. [CrossRef] [PubMed]

33. Robbiani, D.F.; Bozzacco, L.; Keeffe, J.R.; Khouri, R.; Olsen, P.C.; Gazumyan, A.; Schaefer-Babajew, D.; Avila-Rios, S.; Nogueira, L.; Patel, R.; et al. Recurrent Potent Human Neutralizing Antibodies to Zika Virus in Brazil and Mexico. Cell 2017, 169, 597-609. [CrossRef] [PubMed]

34. Ehrhardt, S.A.; Zehner, M.; Krahling, V.; Cohen-Dvashi, H.; Kreer, C.; Elad, N.; Gruell, H.; Ercanoglu, M.S.; Schommers, P.; Gieselmann, L.; et al. Polyclonal and convergent antibody response to Ebola virus vaccine rVSV-ZEBOV. Nat. Med. 2019, 25, 1589-1600. [CrossRef] [PubMed]

35. Hicar, M.D.; Chen, X.; Briney, B.; Hammonds, J.; Wang, J.J.; Kalams, S.; Spearman, P.W.; Crowe, J.E., Jr. Pseudovirion particles bearing native HIV envelope trimers facilitate a novel method for generating human neutralizing monoclonal antibodies against HIV. J. Acquir. Immune Defic. Syndr. 2010, 54, 223-235. [CrossRef]

36. Cale, E.M.; Gorman, J.; Radakovich, N.A.; Crooks, E.T.; Osawa, K.; Tong, T.; Li, J.; Nagarajan, R.; Ozorowski, G.; Ambrozak, D.R.; et al. Virus-like Particles Identify an HIV V1V2 Apex-Binding Neutralizing Antibody that Lacks a Protruding Loop. Immunity 2017, 46, 777-791. [CrossRef]

37. Klein, F.; Gaebler, C.; Mouquet, H.; Sather, D.N.; Lehmann, C.; Scheid, J.F.; Kraft, Z.; Liu, Y.; Pietzsch, J.; Hurley, A.; et al. Broad neutralization by a combination of antibodies recognizing the CD4 binding site and a new conformational epitope on the HIV-1 envelope protein. J. Exp. Med. 2012, 209, 1469-1479. [CrossRef]

38. Woda, M.; Mathew, A. Fluorescently labeled dengue viruses as probes to identify antigen-specific memory B cells by multiparametric flow cytometry. J. Immunol. Methods 2015, 416, 167-177. [CrossRef]

39. Burton, D.R.; Barbas, C.F.; Persson, M.A., 3rd; Koenig, S.; Chanock, R.M.; Lerner, R.A. A large array of human monoclonal antibodies to type 1 human immunodeficiency virus from combinatorial libraries of asymptomatic seropositive individuals. Proc. Natl. Acad. Sci. USA 1991, 88, 10134-10137. [CrossRef]

40. Walker, L.M.; Bowley, D.R.; Burton, D.R. Efficient recovery of high-affinity antibodies from a single-chain Fab yeast display library. J. Mol. Biol. 2009, 389, 365-375. [CrossRef]

41. Traggiai, E.; Becker, S.; Subbarao, K.; Kolesnikova, L.; Uematsu, Y.; Gismondo, M.R.; Murphy, B.R.; Rappuoli, R.; Lanzavecchia, A. An efficient method to make human monoclonal antibodies from memory B cells: Potent neutralization of SARS coronavirus. Nat. Med. 2004, 10, 871-875. [CrossRef] [PubMed]

42. Walker, L.M.; Phogat, S.K.; Chan-Hui, P.Y.; Wagner, D.; Phung, P.; Goss, J.L.; Wrin, T.; Simek, M.D.; Fling, S.; Mitcham, J.L.; et al. Broad and potent neutralizing antibodies from an African donor reveal a new HIV-1 vaccine target. Science 2009, 326, 285-289. [CrossRef] [PubMed]

43. Corti, D.; Voss, J.; Gamblin, S.J.; Codoni, G.; Macagno, A.; Jarrossay, D.; Vachieri, S.G.; Pinna, D.; Minola, A.; Vanzetta, F.; et al. A neutralizing antibody selected from plasma cells that binds to group 1 and group 2 influenza A hemagglutinins. Science 2011, 333, 850-856. [CrossRef] [PubMed]

44. De Benedictis, P.; Minola, A.; Rota Nodari, E.; Aiello, R.; Zecchin, B.; Salomoni, A.; Foglierini, M.; Agatic, G.; Vanzetta, F.; Lavenir, R.; et al. Development of broad-spectrum human monoclonal antibodies for rabies post-exposure prophylaxis. EMBO Mol. Med. 2016, 8, 407-421. [CrossRef] [PubMed]

45. Sanders, R.W.; Derking, R.; Cupo, A.; Julien, J.P.; Yasmeen, A.; de Val, N.; Kim, H.J.; Blattner, C.; de la Pena, A.T.; Korzun, J.; et al. A next-generation cleaved, soluble HIV-1 Env trimer, BG505 SOSIP.664 gp140, expresses multiple epitopes for broadly neutralizing but not non-neutralizing antibodies. PLoS Pathog. 2013, 9, e1003618. [CrossRef] [PubMed]

46. Van Gils, M.J.; van den Kerkhof, T.L.; Ozorowski, G.; Cottrell, C.A.; Sok, D.; Pauthner, M.; Pallesen, J.; de Val, N.; Yasmeen, A.; de Taeye, S.W.; et al. An HIV-1 antibody from an elite neutralizer implicates the fusion peptide as a site of vulnerability. Nat. Microbiol. 2016, 2, 16199. [CrossRef]

47. Kong, R.; Xu, K.; Zhou, T.; Acharya, P.; Lemmin, T.; Liu, K.; Ozorowski, G.; Soto, C.; Taft, J.D.; Bailer, R.T.; et al. Fusion peptide of HIV-1 as a site of vulnerability to neutralizing antibody. Science 2016, 352, 828-833. [CrossRef] 
48. Doria-Rose, N.A.; Bhiman, J.N.; Roark, R.S.; Schramm, C.A.; Gorman, J.; Chuang, G.Y.; Pancera, M.; Cale, E.M.; Ernandes, M.J.; Louder, M.K.; et al. New Member of the V1V2-Directed CAP256-VRC26 Lineage That Shows Increased Breadth and Exceptional Potency. J. Virol. 2016, 90, 76-91. [CrossRef]

49. Setliff, I.; Shiakolas, A.R.; Pilewski, K.A.; Murji, A.A.; Mapengo, R.E.; Janowska, K.; Richardson, S.; Oosthuysen, C.; Raju, N.; Ronsard, L.; et al. High-Throughput Mapping of B Cell Receptor Sequences to Antigen Specificity. Cell 2019, 179, 1636-1646. [CrossRef]

50. Boyd, S.D.; Marshall, E.L.; Merker, J.D.; Maniar, J.M.; Zhang, L.N.; Sahaf, B.; Jones, C.D.; Simen, B.B.; Hanczaruk, B.; Nguyen, K.D.; et al. Measurement and clinical monitoring of human lymphocyte clonality by massively parallel VDJ pyrosequencing. Sci. Transl. Med. 2009, 1, 12ra23. [CrossRef]

51. Wu, Y.C.; Kipling, D.; Leong, H.S.; Martin, V.; Ademokun, A.A.; Dunn-Walters, D.K. High-throughput immunoglobulin repertoire analysis distinguishes between human IgM memory and switched memory B-cell populations. Blood 2010, 116, 1070-1078. [CrossRef] [PubMed]

52. Glanville, J.; Kuo, T.C.; von Budingen, H.C.; Guey, L.; Berka, J.; Sundar, P.D.; Huerta, G.; Mehta, G.R.; Oksenberg, J.R.; Hauser, S.L.; et al. Naive antibody gene-segment frequencies are heritable and unaltered by chronic lymphocyte ablation. Proc. Natl. Acad. Sci. USA 2011, 108, 20066-20071. [CrossRef] [PubMed]

53. Soto, C.; Bombardi, R.G.; Branchizio, A.; Kose, N.; Matta, P.; Sevy, A.M.; Sinkovits, R.S.; Gilchuk, P.; Finn, J.A.; Crowe, J.E., Jr. High frequency of shared clonotypes in human B cell receptor repertoires. Nature 2019, 566, 398-402. [CrossRef] [PubMed]

54. Nielsen, S.C.A.; Roskin, K.M.; Jackson, K.J.L.; Joshi, S.A.; Nejad, P.; Lee, J.Y.; Wagar, L.E.; Pham, T.D.; Hoh, R.A.; Nguyen, K.D.; et al. Shaping of infant B cell receptor repertoires by environmental factors and infectious disease. Sci. Transl. Med. 2019, 11, eaat2004. [CrossRef] [PubMed]

55. Briney, B.; Inderbitzin, A.; Joyce, C.; Burton, D.R. Commonality despite exceptional diversity in the baseline human antibody repertoire. Nature 2019, 566, 393-397. [CrossRef] [PubMed]

56. Zhu, J.; Ofek, G.; Yang, Y.; Zhang, B.; Louder, M.K.; Lu, G.; McKee, K.; Pancera, M.; Skinner, J.; Zhang, Z.; et al. Mining the antibodyome for HIV-1-neutralizing antibodies with next-generation sequencing and phylogenetic pairing of heavy/light chains. Proc. Natl. Acad. Sci. USA 2013, 110, 6470-6475. [CrossRef]

57. Wardemann, H.; Yurasov, S.; Schaefer, A.; Young, J.W.; Meffre, E.; Nussenzweig, M.C. Predominant autoantibody production by early human B cell precursors. Science 2003, 301, 1374-1377. [CrossRef]

58. Tiller, T.; Meffre, E.; Yurasov, S.; Tsuiji, M.; Nussenzweig, M.C.; Wardemann, H. Efficient generation of monoclonal antibodies from single human B cells by single cell RT-PCR and expression vector cloning. J. Immunol. Methods 2008, 329, 112-124. [CrossRef]

59. Busse, C.E.; Czogiel, I.; Braun, P.; Arndt, P.F.; Wardemann, H. Single-cell based high-throughput sequencing of full-length immunoglobulin heavy and light chain genes. Eur. J. Immunol. 2014, 44, 597-603. [CrossRef]

60. Tan, Y.C.; Blum, L.K.; Kongpachith, S.; Ju, C.H.; Cai, X.; Lindstrom, T.M.; Sokolove, J.; Robinson, W.H. High-throughput sequencing of natively paired antibody chains provides evidence for original antigenic sin shaping the antibody response to influenza vaccination. Clin. Immunol. 2014, 151, 55-65. [CrossRef]

61. Mazutis, L.; Gilbert, J.; Ung, W.L.; Weitz, D.A.; Griffiths, A.D.; Heyman, J.A. Single-cell analysis and sorting using droplet-based microfluidics. Nat. Protoc. 2013, 8, 870-891. [CrossRef] [PubMed]

62. McDaniel, J.R.; DeKosky, B.J.; Tanno, H.; Ellington, A.D.; Georgiou, G. Ultra-high-throughput sequencing of the immune receptor repertoire from millions of lymphocytes. Nat. Protoc. 2016, 11, 429-442. [CrossRef] [PubMed]

63. Singh, M.; Al-Eryani, G.; Carswell, S.; Ferguson, J.M.; Blackburn, J.; Barton, K.; Roden, D.; Luciani, F.; Giang Phan, T.; Junankar, S.; et al. High-throughput targeted long-read single cell sequencing reveals the clonal and transcriptional landscape of lymphocytes. Nat. Commun. 2019, 10, 3120. [CrossRef] [PubMed]

64. Briggs, A.; Goldfless, S.; Timberlake, S.; Belmont, B.; Clouser, C.; Koppstein, D.; Sok, D.; Heiden, J.V.; Tamminen, M.; Kleinstein, S.; et al. Tumor-infiltrating immune repertoires captured by single-cell barcoding in emulsion. BioRxiv 2017, 134841. [CrossRef]

65. Goldstein, L.D.; Chen, Y.J.; Wu, J.; Chaudhuri, S.; Hsiao, Y.C.; Schneider, K.; Hoi, K.H.; Lin, Z.; Guerrero, S.; Jaiswal, B.S.; et al. Massively parallel single-cell B-cell receptor sequencing enables rapid discovery of diverse antigen-reactive antibodies. Commun. Biol. 2019, 2, 304. [CrossRef]

66. Bradbury, A.R.; Sidhu, S.; Dubel, S.; McCafferty, J. Beyond natural antibodies: The power of in vitro display technologies. Nat. Biotechnol. 2011, 29, 245-254. [CrossRef] 
67. Larrick, J.W.; Danielsson, L.; Brenner, C.A.; Abrahamson, M.; Fry, K.E.; Borrebaeck, C.A. Rapid cloning of rearranged immunoglobulin genes from human hybridoma cells using mixed primers and the polymerase chain reaction. Biochem. Biophys. Res. Commun. 1989, 160, 1250-1256. [CrossRef]

68. Kuppers, R.; Zhao, M.; Hansmann, M.L.; Rajewsky, K. Tracing B cell development in human germinal centres by molecular analysis of single cells picked from histological sections. EMBO J. 1993, 12, 4955-4967. [CrossRef]

69. Sblattero, D.; Bradbury, A. A definitive set of oligonucleotide primers for amplifying human V regions. Immunotechnology 1998, 3, 271-278. [CrossRef]

70. Lim, T.S.; Mollova, S.; Rubelt, F.; Sievert, V.; Dubel, S.; Lehrach, H.; Konthur, Z. V-gene amplification revisited-An optimised procedure for amplification of rearranged human antibody genes of different isotypes. N. Biotechnol. 2010, 27, 108-117. [CrossRef]

71. Ippolito, G.C.; Hoi, K.H.; Reddy, S.T.; Carroll, S.M.; Ge, X.; Rogosch, T.; Zemlin, M.; Shultz, L.D.; Ellington, A.D.; Vandenberg, C.L.; et al. Antibody repertoires in humanized NOD-scid-IL2Rgamma(null) mice and human B cells reveals human-like diversification and tolerance checkpoints in the mouse. PLoS ONE 2012, 7, e35497. [CrossRef] [PubMed]

72. Scheid, J.F.; Mouquet, H.; Ueberheide, B.; Diskin, R.; Klein, F.; Oliveira, T.Y.; Pietzsch, J.; Fenyo, D.; Abadir, A.; Velinzon, K.; et al. Sequence and structural convergence of broad and potent HIV antibodies that mimic CD4 binding. Science 2011, 333, 1633-1637. [CrossRef] [PubMed]

73. Klein, F.; Mouquet, H.; Dosenovic, P.; Scheid, J.F.; Scharf, L.; Nussenzweig, M.C. Antibodies in HIV-1 vaccine development and therapy. Science 2013, 341, 1199-1204. [CrossRef] [PubMed]

74. Kreer, C.; Doering, M.; Lehnen, N.; Ercanoglu, M.S.; Gieselmann, L.; Luca, D.; Jain, K.; Schommers, P.; Pfeifer, N.; Klein, F. OpenPrimer for multiplex amplification of highly diverse templates. BioRxiv 2019, 847574. [CrossRef]

75. He, L.; Sok, D.; Azadnia, P.; Hsueh, J.; Landais, E.; Simek, M.; Koff, W.C.; Poignard, P.; Burton, D.R.; Zhu, J. Toward a more accurate view of human B-cell repertoire by next-generation sequencing, unbiased repertoire capture and single-molecule barcoding. Sci. Rep. 2014, 4, 6778. [CrossRef]

76. Frohman, M.A.; Dush, M.K.; Martin, G.R. Rapid production of full-length cDNAs from rare transcripts: Amplification using a single gene-specific oligonucleotide primer. Proc. Natl. Acad. Sc.i USA 1988, 85, 8998-9002. [CrossRef]

77. Huang, C.; Stollar, B.D. Construction of representative immunoglobulin variable region cDNA libraries from human peripheral blood lymphocytes without in vitro stimulation. J. Immunol. Methods 1991, 141, 227-236. [CrossRef]

78. Ozawa, T.; Kishi, H.; Muraguchi, A. Amplification and analysis of cDNA generated from a single cell by 5'-RACE: Application to isolation of antibody heavy and light chain variable gene sequences from single B cells. Biotechniques 2006, 40, 469-470. [CrossRef]

79. Rollenske, T.; Szijarto, V.; Lukasiewicz, J.; Guachalla, L.M.; Stojkovic, K.; Hartl, K.; Stulik, L.; Kocher, S.; Lasitschka, F.; Al-Saeedi, M.; et al. Cross-specificity of protective human antibodies against Klebsiella pneumoniae LPS O-antigen. Nat. Immunol. 2018, 19, 617-624. [CrossRef]

80. Olbrich, A.; Wardemann, H.; Bohm, S.; Rother, K.; Colpitts, C.C.; Wrensch, F.; Baumert, T.F.; Berg, T.; Benckert, J. Repertoire and Neutralizing Activity of Antibodies Against Hepatitis C Virus E2 Peptide in Patients with Spontaneous Resolution of Hepatitis, C. J. Infect. Dis. 2019, 220, 1209-1218. [CrossRef]

81. Greiff, V.; Miho, E.; Menzel, U.; Reddy, S.T. Bioinformatic and Statistical Analysis of Adaptive Immune Repertoires. Trends Immunol. 2015, 36, 738-749. [CrossRef] [PubMed]

82. DeKosky, B.J.; Kojima, T.; Rodin, A.; Charab, W.; Ippolito, G.C.; Ellington, A.D.; Georgiou, G. In-depth determination and analysis of the human paired heavy- and light-chain antibody repertoire. Nat. Med. 2015, 21, 86-91. [CrossRef] [PubMed]

83. Chaudhary, N.; Wesemann, D.R. Analyzing Immunoglobulin Repertoires. Front. Immunol. 2018, 9, 462. [CrossRef] [PubMed]

84. Vander Heiden, J.A.; Marquez, S.; Marthandan, N.; Bukhari, S.A.C.; Busse, C.E.; Corrie, B.; Hershberg, U.; Kleinstein, S.H.; Matsen Iv, F.A.; Ralph, D.K.; et al. AIRR Community Standardized Representations for Annotated Immune Repertoires. Front. Immunol. 2018, 9, 2206. [CrossRef] 
85. Corrie, B.D.; Marthandan, N.; Zimonja, B.; Jaglale, J.; Zhou, Y.; Barr, E.; Knoetze, N.; Breden, F.M.W.; Christley, S.; Scott, J.K.; et al. iReceptor: A platform for querying and analyzing antibody/B-cell and T-cell receptor repertoire data across federated repositories. Immunol. Rev. 2018, 284, 24-41. [CrossRef]

86. Miho, E.; Yermanos, A.; Weber, C.R.; Berger, C.T.; Reddy, S.T.; Greiff, V. Computational Strategies for Dissecting the High-Dimensional Complexity of Adaptive Immune Repertoires. Front. Immunol. 2018, 9, 224. [CrossRef]

87. Williams, L.D.; Ofek, G.; Schatzle, S.; McDaniel, J.R.; Lu, X.; Nicely, N.I.; Wu, L.; Lougheed, C.S.; Bradley, T.; Louder, M.K.; et al. Potent and broad HIV-neutralizing antibodies in memory B cells and plasma. Sci. Immunol. 2017, 2, eaal2200. [CrossRef]

88. Sajadi, M.M.; Dashti, A.; Rikhtegaran Tehrani, Z.; Tolbert, W.D.; Seaman, M.S.; Ouyang, X.; Gohain, N.; Pazgier, M.; Kim, D.; Cavet, G.; et al. Identification of Near-Pan-neutralizing Antibodies against HIV-1 by Deconvolution of Plasma Humoral Responses. Cell 2018, 173, 1783-1795. [CrossRef]

89. Sok, D.; Burton, D.R. Recent progress in broadly neutralizing antibodies to HIV. Nat. Immunol. 2018, 19, 1179-1188. [CrossRef]

90. Lynch, R.M.; Boritz, E.; Coates, E.E.; DeZure, A.; Madden, P.; Costner, P.; Enama, M.E.; Plummer, S.; Holman, L.; Hendel, C.S.; et al. Virologic effects of broadly neutralizing antibody VRC01 administration during chronic HIV-1 infection. Sci. Transl. Med. 2015, 7, 319ra206. [CrossRef]

91. Caskey, M.; Klein, F.; Lorenzi, J.C.; Seaman, M.S.; West, A.P., Jr.; Buckley, N.; Kremer, G.; Nogueira, L.; Braunschweig, M.; Scheid, J.F.; et al. Viraemia suppressed in HIV-1-infected humans by broadly neutralizing antibody 3BNC117. Nature 2015, 522, 487-491. [CrossRef] [PubMed]

92. Bar, K.J.; Sneller, M.C.; Harrison, L.J.; Justement, J.S.; Overton, E.T.; Petrone, M.E.; Salantes, D.B.; Seamon, C.A.; Scheinfeld, B.; Kwan, R.W.; et al. Effect of HIV Antibody VRC01 on Viral Rebound after Treatment Interruption. N. Engl. J. Med. 2016, 375, 2037-2050. [CrossRef]

93. Scheid, J.F.; Horwitz, J.A.; Bar-On, Y.; Kreider, E.F.; Lu, C.L.; Lorenzi, J.C.; Feldmann, A.; Braunschweig, M.; Nogueira, L.; Oliveira, T.; et al. HIV-1 antibody 3BNC117 suppresses viral rebound in humans during treatment interruption. Nature 2016, 535, 556-560. [CrossRef] [PubMed]

94. Caskey, M.; Schoofs, T.; Gruell, H.; Settler, A.; Karagounis, T.; Kreider, E.F.; Murrell, B.; Pfeifer, N.; Nogueira, L.; Oliveira, T.Y.; et al. Antibody 10-1074 suppresses viremia in HIV-1-infected individuals. Nat. Med. 2017, 23, 185-191. [CrossRef] [PubMed]

95. Bar-On, Y.; Gruell, H.; Schoofs, T.; Pai, J.A.; Nogueira, L.; Butler, A.L.; Millard, K.; Lehmann, C.; Suarez, I.; Oliveira, T.Y.; et al. Safety and antiviral activity of combination HIV-1 broadly neutralizing antibodies in viremic individuals. Nat. Med. 2018, 24, 1701-1707. [CrossRef]

96. Mendoza, P.; Gruell, H.; Nogueira, L.; Pai, J.A.; Butler, A.L.; Millard, K.; Lehmann, C.; Suarez, I.; Oliveira, T.Y.; Lorenzi, J.C.C.; et al. Combination therapy with anti-HIV-1 antibodies maintains viral suppression. Nature 2018, 561, 479-484. [CrossRef]

97. Moldt, B.; Rakasz, E.G.; Schultz, N.; Chan-Hui, P.Y.; Swiderek, K.; Weisgrau, K.L.; Piaskowski, S.M.; Bergman, Z.; Watkins, D.I.; Poignard, P.; et al. Highly potent HIV-specific antibody neutralization in vitro translates into effective protection against mucosal SHIV challenge in vivo. Proc. Natl. Acad. Sci. USA 2012, 109, 18921-18925. [CrossRef]

98. Shingai, M.; Donau, O.K.; Plishka, R.J.; Buckler-White, A.; Mascola, J.R.; Nabel, G.J.; Nason, M.C.; Montefiori, D.; Moldt, B.; Poignard, P.; et al. Passive transfer of modest titers of potent and broadly neutralizing anti-HIV monoclonal antibodies block SHIV infection in macaques. J. Exp. Med. 2014, 211, 2061-2074. [CrossRef]

99. Gautam, R.; Nishimura, Y.; Pegu, A.; Nason, M.C.; Klein, F.; Gazumyan, A.; Golijanin, J.; Buckler-White, A.; Sadjadpour, R.; Wang, K.; et al. A single injection of anti-HIV-1 antibodies protects against repeated SHIV challenges. Nature 2016, 533, 105-109. [CrossRef]

100. Julg, B.; Tartaglia, L.J.; Keele, B.F.; Wagh, K.; Pegu, A.; Sok, D.; Abbink, P.; Schmidt, S.D.; Wang, K.; Chen, X.; et al. Broadly neutralizing antibodies targeting the HIV-1 envelope V2 apex confer protection against a clade C SHIV challenge. Sci. Transl. Med. 2017, 9, eaal1321. [CrossRef]

101. Zhou, T.; Lynch, R.M.; Chen, L.; Acharya, P.; Wu, X.; Doria-Rose, N.A.; Joyce, M.G.; Lingwood, D.; Soto, C.; Bailer, R.T.; et al. Structural Repertoire of HIV-1-Neutralizing Antibodies Targeting the CD4 Supersite in 14 Donors. Cell 2015, 161, 280-292. [CrossRef] [PubMed] 
102. Zhou, T.; Zhu, J.; Wu, X.; Moquin, S.; Zhang, B.; Acharya, P.; Georgiev, I.S.; Altae-Tran, H.R.; Chuang, G.Y.; Joyce, M.G.; et al. Multidonor analysis reveals structural elements, genetic determinants, and maturation pathway for HIV-1 neutralization by VRC01-class antibodies. Immunity 2013, 39, 245-258. [CrossRef] [PubMed]

103. Wu, X.; Zhou, T.; Zhu, J.; Zhang, B.; Georgiev, I.; Wang, C.; Chen, X.; Longo, N.S.; Louder, M.; McKee, K.; et al. Focused evolution of HIV-1 neutralizing antibodies revealed by structures and deep sequencing. Science 2011, 333, 1593-1602. [CrossRef] [PubMed]

104. Huang, J.; Kang, B.H.; Ishida, E.; Zhou, T.; Griesman, T.; Sheng, Z.; Wu, F.; Doria-Rose, N.A.; Zhang, B.; McKee, K.; et al. Identification of a CD4-Binding-Site Antibody to HIV that Evolved Near-Pan Neutralization Breadth. Immunity 2016, 45, 1108-1121. [CrossRef] [PubMed]

105. Umotoy, J.; Bagaya, B.S.; Joyce, C.; Schiffner, T.; Menis, S.; Saye-Francisco, K.L.; Biddle, T.; Mohan, S.; Vollbrecht, T.; Kalyuzhniy, O.; et al. Rapid and Focused Maturation of a VRC01-Class HIV Broadly Neutralizing Antibody Lineage Involves Both Binding and Accommodation of the N276-Glycan. Immunity 2019, 51, 141-154. [CrossRef]

106. Georgiev, I.S.; Doria-Rose, N.A.; Zhou, T.; Kwon, Y.D.; Staupe, R.P.; Moquin, S.; Chuang, G.Y.; Louder, M.K.; Schmidt, S.D.; Altae-Tran, H.R.; et al. Delineating antibody recognition in polyclonal sera from patterns of HIV-1 isolate neutralization. Science 2013, 340, 751-756. [CrossRef]

107. Godoy-Lozano, E.E.; Tellez-Sosa, J.; Sanchez-Gonzalez, G.; Samano-Sanchez, H.; Aguilar-Salgado, A.; Salinas-Rodriguez, A.; Cortina-Ceballos, B.; Vivanco-Cid, H.; Hernandez-Flores, K.; Pfaff, J.M.; et al. Lower IgG somatic hypermutation rates during acute dengue virus infection is compatible with a germinal center-independent B cell response. Genome Med. 2016, 8, 23. [CrossRef]

108. Farci, P.; Diaz, G.; Chen, Z.; Govindarajan, S.; Tice, A.; Agulto, L.; Pittaluga, S.; Boon, D.; Yu, C.; Engle, R.E.; et al. B cell gene signature with massive intrahepatic production of antibodies to hepatitis B core antigen in hepatitis B virus-associated acute liver failure. Proc. Natl. Acad. Sci. USA 2010, 107, 8766-8771. [CrossRef]

109. Weitkamp, J.H.; Kallewaard, N.; Kusuhara, K.; Bures, E.; Williams, J.V.; LaFleur, B.; Greenberg, H.B.; Crowe, J.E., Jr. Infant and adult human B cell responses to rotavirus share common immunodominant variable gene repertoires. J. Immunol. 2003, 171, 4680-4688. [CrossRef]

110. Weitkamp, J.H.; Kallewaard, N.L.; Bowen, A.L.; Lafleur, B.J.; Greenberg, H.B.; Crowe, J.E., Jr. VH1-46 is the dominant immunoglobulin heavy chain gene segment in rotavirus-specific memory B cells expressing the intestinal homing receptor alpha4beta7. J. Immunol. 2005, 174, 3454-3460. [CrossRef]

111. Tian, C.; Luskin, G.K.; Dischert, K.M.; Higginbotham, J.N.; Shepherd, B.E.; Crowe, J.E., Jr. Immunodominance of the VH1-46 antibody gene segment in the primary repertoire of human rotavirus-specific B cells is reduced in the memory compartment through somatic mutation of nondominant clones. J. Immunol. 2008, 180, 3279-3288. [CrossRef] [PubMed]

112. Scheepers, C.; Shrestha, R.K.; Lambson, B.E.; Jackson, K.J.; Wright, I.A.; Naicker, D.; Goosen, M.; Berrie, L.; Ismail, A.; Garrett, N.; et al. Ability to develop broadly neutralizing HIV-1 antibodies is not restricted by the germline Ig gene repertoire. J. Immunol. 2015, 194, 4371-4378. [CrossRef] [PubMed]

113. Sui, J.; Hwang, W.C.; Perez, S.; Wei, G.; Aird, D.; Chen, L.M.; Santelli, E.; Stec, B.; Cadwell, G.; Ali, M.; et al. Structural and functional bases for broad-spectrum neutralization of avian and human influenza A viruses. Nat. Struct. Mol. Biol. 2009, 16, 265-273. [CrossRef] [PubMed]

114. Corti, D.; Suguitan, A.L., Jr.; Pinna, D.; Silacci, C.; Fernandez-Rodriguez, B.M.; Vanzetta, F.; Santos, C.; Luke, C.J.; Torres-Velez, F.J.; Temperton, N.J.; et al. Heterosubtypic neutralizing antibodies are produced by individuals immunized with a seasonal influenza vaccine. J. Clin. Invest. 2010, 120, 1663-1673. [CrossRef]

115. Pappas, L.; Foglierini, M.; Piccoli, L.; Kallewaard, N.L.; Turrini, F.; Silacci, C.; Fernandez-Rodriguez, B.; Agatic, G.; Giacchetto-Sasselli, I.; Pellicciotta, G.; et al. Rapid development of broadly influenza neutralizing antibodies through redundant mutations. Nature 2014, 516, 418-422. [CrossRef]

116. Buchacher, A.; Predl, R.; Strutzenberger, K.; Steinfellner, W.; Trkola, A.; Purtscher, M.; Gruber, G.; Tauer, C.; Steindl, F.; Jungbauer, A.; et al. Generation of human monoclonal antibodies against HIV-1 proteins; electrofusion and Epstein-Barr virus transformation for peripheral blood lymphocyte immortalization. AIDS Res. Hum. Retrovir. 1994, 10, 359-369. [CrossRef]

117. Galson, J.D.; Truck, J.; Clutterbuck, E.A.; Fowler, A.; Cerundolo, V.; Pollard, A.J.; Lunter, G.; Kelly, D.F. B-cell repertoire dynamics after sequential hepatitis $\mathrm{B}$ vaccination and evidence for cross-reactive B-cell activation. Genome Med. 2016, 8, 68. [CrossRef] 
118. Jackson, K.J.; Liu, Y.; Roskin, K.M.; Glanville, J.; Hoh, R.A.; Seo, K.; Marshall, E.L.; Gurley, T.C.; Moody, M.A.; Haynes, B.F.; et al. Human responses to influenza vaccination show seroconversion signatures and convergent antibody rearrangements. Cell Host Microbe 2014, 16, 105-114. [CrossRef]

119. Rijal, P.; Elias, S.C.; Machado, S.R.; Xiao, J.; Schimanski, L.; O’Dowd, V.; Baker, T.; Barry, E.; Mendelsohn, S.C.; Cherry, C.J.; et al. Therapeutic Monoclonal Antibodies for Ebola Virus Infection Derived from Vaccinated Humans. Cell Rep. 2019, 27, 172-186. [CrossRef]

120. Bornholdt, Z.A.; Turner, H.L.; Murin, C.D.; Li, W.; Sok, D.; Souders, C.A.; Piper, A.E.; Goff, A.; Shamblin, J.D.; Wollen, S.E.; et al. Isolation of potent neutralizing antibodies from a survivor of the 2014 Ebola virus outbreak. Science 2016, 351, 1078-1083. [CrossRef]

121. Lucas, A.H.; McLean, G.R.; Reason, D.C.; O'Connor, A.P.; Felton, M.C.; Moulton, K.D. Molecular ontogeny of the human antibody repertoire to the Haemophilus influenzae type B polysaccharide: Expression of canonical variable regions and their variants in vaccinated infants. Clin. Immunol. 2003, 108, 119-127. [CrossRef]

122. Thomson, C.A.; Bryson, S.; McLean, G.R.; Creagh, A.L.; Pai, E.F.; Schrader, J.W. Germline V-genes sculpt the binding site of a family of antibodies neutralizing human cytomegalovirus. EMBO J. 2008, 27, 2592-2602. [CrossRef]

123. Bryson, S.; Thomson, C.A.; Risnes, L.F.; Dasgupta, S.; Smith, K.; Schrader, J.W.; Pai, E.F. Structures of Preferred Human IgV Genes-Based Protective Antibodies Identify How Conserved Residues Contact Diverse Antigens and Assign Source of Specificity to CDR3 Loop Variation. J. Immunol. 2016, 196, 4723-4730. [CrossRef]

124. Stettler, K.; Beltramello, M.; Espinosa, D.A.; Graham, V.; Cassotta, A.; Bianchi, S.; Vanzetta, F.; Minola, A.; Jaconi, S.; Mele, F.; et al. Specificity, cross-reactivity, and function of antibodies elicited by Zika virus infection. Science 2016, 353, 823-826. [CrossRef] [PubMed]

125. Sapparapu, G.; Fernandez, E.; Kose, N.; Bin, C.; Fox, J.M.; Bombardi, R.G.; Zhao, H.; Nelson, C.A.; Bryan, A.L.; Barnes, T.; et al. Neutralizing human antibodies prevent Zika virus replication and fetal disease in mice. Nature 2016, 540, 443-447. [CrossRef] [PubMed]

126. Wu, Y.; Li, S.; Du, L.; Wang, C.; Zou, P.; Hong, B.; Yuan, M.; Ren, X.; Tai, W.; Kong, Y.; et al. Neutralization of Zika virus by germline-like human monoclonal antibodies targeting cryptic epitopes on envelope domain III. Emerg. Microbes Infect. 2017, 6, e89. [CrossRef] [PubMed]

127. Gorny, M.K.; Wang, X.H.; Williams, C.; Volsky, B.; Revesz, K.; Witover, B.; Burda, S.; Urbanski, M.; Nyambi, P.; Krachmarov, C.; et al. Preferential use of the VH5-51 gene segment by the human immune response to code for antibodies against the V3 domain of HIV-1. Mol. Immunol. 2009, 46, 917-926. [CrossRef]

128. West, A.P., Jr.; Diskin, R.; Nussenzweig, M.C.; Bjorkman, P.J. Structural basis for germ-line gene usage of a potent class of antibodies targeting the CD4-binding site of HIV-1 gp120. Proc. Natl. Acad. Sci. USA 2012, 109, E2083-E2090. [CrossRef]

129. McLellan, J.S.; Pancera, M.; Carrico, C.; Gorman, J.; Julien, J.P.; Khayat, R.; Louder, R.; Pejchal, R.; Sastry, M.; Dai, K.; et al. Structure of HIV-1 gp120 V1/V2 domain with broadly neutralizing antibody PG9. Nature 2011, 480, 336-343. [CrossRef]

130. Lee, J.H.; Andrabi, R.; Su, C.Y.; Yasmeen, A.; Julien, J.P.; Kong, L.; Wu, N.C.; McBride, R.; Sok, D.; Pauthner, M.; et al. A Broadly Neutralizing Antibody Targets the Dynamic HIV Envelope Trimer Apex via a Long, Rigidified, and Anionic beta-Hairpin Structure. Immunity 2017, 46, 690-702. [CrossRef]

131. DeKosky, B.J.; Lungu, O.I.; Park, D.; Johnson, E.L.; Charab, W.; Chrysostomou, C.; Kuroda, D.; Ellington, A.D.; Ippolito, G.C.; Gray, J.J.; et al. Large-scale sequence and structural comparisons of human naive and antigen-experienced antibody repertoires. Proc. Natl. Acad. Sci. USA 2016, 113, E2636-E2645. [CrossRef]

132. Haynes, B.F.; Fleming, J.; St Clair, E.W.; Katinger, H.; Stiegler, G.; Kunert, R.; Robinson, J.; Scearce, R.M.; Plonk, K.; Staats, H.F.; et al. Cardiolipin polyspecific autoreactivity in two broadly neutralizing HIV-1 antibodies. Science 2005, 308, 1906-1908. [CrossRef] [PubMed]

133. Mascola, J.R.; Haynes, B.F. HIV-1 neutralizing antibodies: Understanding nature's pathways. Immunol. Rev. 2013, 254, 225-244. [CrossRef] [PubMed]

134. Simonich, C.A.; Williams, K.L.; Verkerke, H.P.; Williams, J.A.; Nduati, R.; Lee, K.K.; Overbaugh, J. HIV-1 Neutralizing Antibodies with Limited Hypermutation from an Infant. Cell 2016, 166, 77-87. [CrossRef] [PubMed] 
135. MacLeod, D.T.; Choi, N.M.; Briney, B.; Garces, F.; Ver, L.S.; Landais, E.; Murrell, B.; Wrin, T.; Kilembe, W.; Liang, C.H.; et al. Early Antibody Lineage Diversification and Independent Limb Maturation Lead to Broad HIV-1 Neutralization Targeting the Env High-Mannose Patch. Immunity 2016, 44, 1215-1226. [CrossRef]

136. Kwong, P.D.; Mascola, J.R. HIV-1 Vaccines Based on Antibody Identification, B Cell Ontogeny, and Epitope Structure. Immunity 2018, 48, 855-871. [CrossRef]

137. Hoot, S.; McGuire, A.T.; Cohen, K.W.; Strong, R.K.; Hangartner, L.; Klein, F.; Diskin, R.; Scheid, J.F.; Sather, D.N.; Burton, D.R.; et al. Recombinant HIV envelope proteins fail to engage germline versions of anti-CD4bs bNAbs. PLoS Pathog. 2013, 9, e1003106. [CrossRef]

138. Zhou, T.; Georgiev, I.; Wu, X.; Yang, Z.Y.; Dai, K.; Finzi, A.; Kwon, Y.D.; Scheid, J.F.; Shi, W.; Xu, L.; et al. Structural basis for broad and potent neutralization of HIV-1 by antibody VRC01. Science 2010, 329, 811-817. [CrossRef]

139. Sok, D.; Laserson, U.; Laserson, J.; Liu, Y.; Vigneault, F.; Julien, J.P.; Briney, B.; Ramos, A.; Saye, K.F.; Le, K.; et al. The effects of somatic hypermutation on neutralization and binding in the PGT121 family of broadly neutralizing HIV antibodies. PLoS Pathog. 2013, 9, e1003754. [CrossRef]

140. Haynes, B.F.; Kelsoe, G.; Harrison, S.C.; Kepler, T.B. B-cell-lineage immunogen design in vaccine development with HIV-1 as a case study. Nat. Biotechnol. 2012, 30, 423-433. [CrossRef]

141. Havenar-Daughton, C.; Abbott, R.K.; Schief, W.R.; Crotty, S. When designing vaccines, consider the starting material: The human B cell repertoire. Curr. Opin. Immunol. 2018, 53, 209-216. [CrossRef] [PubMed]

142. Briney, B.S.; Willis, J.R.; Crowe, J.E., Jr. Human peripheral blood antibodies with long HCDR3s are established primarily at original recombination using a limited subset of germline genes. PLoS ONE 2012, 7, e36750. [CrossRef] [PubMed]

143. Willis, J.R.; Finn, J.A.; Briney, B.; Sapparapu, G.; Singh, V.; King, H.; LaBranche, C.C.; Montefiori, D.C.; Meiler, J.; Crowe, J.E., Jr. Long antibody HCDR3s from HIV-naive donors presented on a PG9 neutralizing antibody background mediate HIV neutralization. Proc. Natl. Acad. Sci. USA 2016, 113, 4446-4451. [CrossRef]

144. Freund, N.T.; Wang, H.; Scharf, L.; Nogueira, L.; Horwitz, J.A.; Bar-On, Y.; Golijanin, J.; Sievers, S.A.; Sok, D.; Cai, H.; et al. Coexistence of potent HIV-1 broadly neutralizing antibodies and antibody-sensitive viruses in a viremic controller. Sci. Transl. Med. 2017, 9, eaal2144. [CrossRef]

145. Barnes, C.O.; Gristick, H.B.; Freund, N.T.; Escolano, A.; Lyubimov, A.Y.; Hartweger, H.; West, A.P., Jr.; Cohen, A.E.; Nussenzweig, M.C.; Bjorkman, P.J. Structural characterization of a highly-potent V3-glycan broadly neutralizing antibody bound to natively-glycosylated HIV-1 envelope. Nat. Commun. 2018, 9, 1251. [CrossRef]

146. Steichen, J.M.; Lin, Y.C.; Havenar-Daughton, C.; Pecetta, S.; Ozorowski, G.; Willis, J.R.; Toy, L.; Sok, D.; Liguori, A.; Kratochvil, S.; et al. A generalized HIV vaccine design strategy for priming of broadly neutralizing antibody responses. Science 2019, 366, eaax4380. [CrossRef]

147. Jardine, J.G.; Kulp, D.W.; Havenar-Daughton, C.; Sarkar, A.; Briney, B.; Sok, D.; Sesterhenn, F.; Ereno-Orbea, J.; Kalyuzhniy, O.; Deresa, I.; et al. HIV-1 broadly neutralizing antibody precursor B cells revealed by germline-targeting immunogen. Science 2016, 351, 1458-1463. [CrossRef] [PubMed]

148. Havenar-Daughton, C.; Sarkar, A.; Kulp, D.W.; Toy, L.; Hu, X.; Deresa, I.; Kalyuzhniy, O.; Kaushik, K.; Upadhyay, A.A.; Menis, S.; et al. The human naive B cell repertoire contains distinct subclasses for a germline-targeting HIV-1 vaccine immunogen. Sci. Transl. Med. 2018, 10, eaat0381. [CrossRef]

149. Yacoob, C.; Pancera, M.; Vigdorovich, V.; Oliver, B.G.; Glenn, J.A.; Feng, J.; Sather, D.N.; McGuire, A.T.; Stamatatos, L. Differences in Allelic Frequency and CDRH3 Region Limit the Engagement of HIV Env Immunogens by Putative VRC01 Neutralizing Antibody Precursors. Cell Rep. 2016, 17, 1560-1570. [CrossRef]

150. Zhu, J.; O'Dell, S.; Ofek, G.; Pancera, M.; Wu, X.; Zhang, B.; Zhang, Z.; Program, N.C.S.; Mullikin, J.C.; Simek, M.; et al. Somatic Populations of PGT135-137 HIV-1-Neutralizing Antibodies Identified by 454 Pyrosequencing and Bioinformatics. Front. Microbiol. 2012, 3, 315. [CrossRef]

151. Zhu, J.; Wu, X.; Zhang, B.; McKee, K.; O’Dell, S.; Soto, C.; Zhou, T.; Casazza, J.P.; Program, N.C.S.; Mullikin, J.C.; et al. De novo identification of VRC01 class HIV-1-neutralizing antibodies by next-generation sequencing of B-cell transcripts. Proc. Natl. Acad. Sci. USA 2013, 110, E4088-E4097. [CrossRef]

152. Doria-Rose, N.A.; Schramm, C.A.; Gorman, J.; Moore, P.L.; Bhiman, J.N.; DeKosky, B.J.; Ernandes, M.J.; Georgiev, I.S.; Kim, H.J.; Pancera, M.; et al. Developmental pathway for potent V1V2-directed HIV-neutralizing antibodies. Nature 2014, 509, 55-62. [CrossRef] 
153. Wu, X.; Zhang, Z.; Schramm, C.A.; Joyce, M.G.; Kwon, Y.D.; Zhou, T.; Sheng, Z.; Zhang, B.; O’Dell, S.; McKee, K.; et al. Maturation and Diversity of the VRC01-Antibody Lineage over 15 Years of Chronic HIV-1 Infection. Cell 2015, 161, 470-485. [CrossRef] [PubMed]

154. Bonsignori, M.; Zhou, T.; Sheng, Z.; Chen, L.; Gao, F.; Joyce, M.G.; Ozorowski, G.; Chuang, G.Y.; Schramm, C.A.; Wiehe, K.; et al. Maturation Pathway from Germline to Broad HIV-1 Neutralizer of a CD4-Mimic Antibody. Cell 2016, 165, 449-463. [CrossRef] [PubMed]

155. Soto, C.; Ofek, G.; Joyce, M.G.; Zhang, B.; McKee, K.; Longo, N.S.; Yang, Y.; Huang, J.; Parks, R.; Eudailey, J.; et al. Developmental Pathway of the MPER-Directed HIV-1-Neutralizing Antibody 10E8. PLoS ONE 2016, 11, e0157409. [CrossRef] [PubMed]

156. Bhiman, J.N.; Anthony, C.; Doria-Rose, N.A.; Karimanzira, O.; Schramm, C.A.; Khoza, T.; Kitchin, D.; Botha, G.; Gorman, J.; Garrett, N.J.; et al. Viral variants that initiate and drive maturation of V1V2-directed HIV-1 broadly neutralizing antibodies. Nat. Med. 2015, 21, 1332-1336. [CrossRef]

157. Landais, E.; Murrell, B.; Briney, B.; Murrell, S.; Rantalainen, K.; Berndsen, Z.T.; Ramos, A.; Wickramasinghe, L.; Smith, M.L.; Eren, K.; et al. HIV Envelope Glycoform Heterogeneity and Localized Diversity Govern the Initiation and Maturation of a V2 Apex Broadly Neutralizing Antibody Lineage. Immunity 2017, 47, 990-1003. [CrossRef]

158. Bonsignori, M.; Kreider, E.F.; Fera, D.; Meyerhoff, R.R.; Bradley, T.; Wiehe, K.; Alam, S.M.; Aussedat, B.; Walkowicz, W.E.; Hwang, K.K.; et al. Staged induction of HIV-1 glycan-dependent broadly neutralizing antibodies. Sci. Transl. Med. 2017, 9, eaai7514. [CrossRef]

159. Rudicell, R.S.; Kwon, Y.D.; Ko, S.Y.; Pegu, A.; Louder, M.K.; Georgiev, I.S.; Wu, X.; Zhu, J.; Boyington, J.C.; Chen, X.; et al. Enhanced potency of a broadly neutralizing HIV-1 antibody in vitro improves protection against lentiviral infection in vivo. J. Virol. 2014, 88, 12669-12682. [CrossRef]

160. Liao, H.X.; Lynch, R.; Zhou, T.; Gao, F.; Alam, S.M.; Boyd, S.D.; Fire, A.Z.; Roskin, K.M.; Schramm, C.A.; Zhang, Z.; et al. Co-evolution of a broadly neutralizing HIV-1 antibody and founder virus. Nature 2013, 496, 469-476. [CrossRef]

161. Gao, F.; Bonsignori, M.; Liao, H.X.; Kumar, A.; Xia, S.M.; Lu, X.; Cai, F.; Hwang, K.K.; Song, H.; Zhou, T.; et al. Cooperation of B cell lineages in induction of HIV-1-broadly neutralizing antibodies. Cell 2014, 158, 481-491. [CrossRef] [PubMed]

162. Chen, W.; Prabakaran, P.; Zhu, Z.; Feng, Y.; Streaker, E.D.; Dimitrov, D.S. Characterization of human IgG repertoires in an acute HIV-1 infection. Exp. Mol. Pathol. 2012, 93, 399-407. [CrossRef] [PubMed]

163. Xiao, M.; Prabakaran, P.; Chen, W.; Kessing, B.; Dimitrov, D.S. Deep sequencing and Circos analyses of antibody libraries reveal antigen-driven selection of Ig VH genes during HIV-1 infection. Exp. Mol. Pathol. 2013, 95, 357-363. [CrossRef] [PubMed]

164. Zhang, Y.; Yuan, T.; Li, J.; Zhang, Y.; Xu, J.; Shao, Y.; Chen, Z.; Zhang, M.Y. The potential of the human immune system to develop broadly neutralizing HIV-1 antibodies: Implications for vaccine development. AIDS 2013, 27, 2529-2539. [CrossRef]

165. Yin, L.; Hou, W.; Liu, L.; Cai, Y.; Wallet, M.A.; Gardner, B.P.; Chang, K.; Lowe, A.C.; Rodriguez, C.A.; Sriaroon, P.; et al. IgM Repertoire Biodiversity is Reduced in HIV-1 Infection and Systemic Lupus Erythematosus. Front. Immunol. 2013, 4, 373. [CrossRef]

166. Hoehn, K.B.; Gall, A.; Bashford-Rogers, R.; Fidler, S.J.; Kaye, S.; Weber, J.N.; McClure, M.O.; Investigators, S.T.; Kellam, P.; Pybus, O.G. Dynamics of immunoglobulin sequence diversity in HIV-1 infected individuals. Philos. Trans. R. Soc. B Biol. Sci. 2015, 370, 20140241. [CrossRef]

167. Waltari, E.; Jia, M.; Jiang, C.S.; Lu, H.; Huang, J.; Fernandez, C.; Finzi, A.; Kaufmann, D.E.; Markowitz, M.; Tsuji, M.; et al. 5' rapid Amplification of cDNA Ends and Illumina MiSeq Reveals B Cell Receptor Features in Healthy Adults, Adults With Chronic HIV-1 Infection, Cord Blood, and Humanized Mice. Front. Immunol. 2018, 9, 628. [CrossRef]

168. Setliff, I.; McDonnell, W.J.; Raju, N.; Bombardi, R.G.; Murji, A.A.; Scheepers, C.; Ziki, R.; Mynhardt, C.; Shepherd, B.E.; Mamchak, A.A.; et al. Multi-Donor Longitudinal Antibody Repertoire Sequencing Reveals the Existence of Public Antibody Clonotypes in HIV-1 Infection. Cell Host Microbe 2018, 23, 845-854. [CrossRef]

(C) 2020 by the authors. Licensee MDPI, Basel, Switzerland. This article is an open access article distributed under the terms and conditions of the Creative Commons Attribution (CC BY) license (http://creativecommons.org/licenses/by/4.0/). 